\title{
Quantum-chemical investigation of the structure and the antioxidant properties of $\alpha$-lipoic acid and its metabolites
}

\author{
Małgorzata Szeląg • Damian Mikulski • Marcin Molski
}

Received: 5 August 2011 /Accepted: 7 November 2011 /Published online: 30 November 2011

(C) The Author(s) 2011. This article is published with open access at Springerlink.com

\begin{abstract}
Quantum-chemical computations were used to investigate the structure-antioxidant parameter relationships of $\alpha$-lipoic acid and its natural metabolites bisnorlipoic acid and tetranorlipoic acid in their oxidized and reduced forms. The enantiomers of lipoic and dihydrolipoic acid were optimized using the B3LYP/6-311+G(3df,2p), B3LYP/aug-cc-pVDZ and MP2(full)/6-31+G(d,p) levels of theory as isolated molecules and in the presence of water. The geometries of the metabolites and the values of their antioxidant parameters (proton affinity, bond dissociation enthalpy, adiabatic ionization potential, spin density, and the highest occupied molecular orbital energy) were calculated at the B3LYP/6-311+G(3df,2p) level of theory. The results obtained reveal similarities between these structures: a pentatomic, nonaromatic ring is present in the oxidized forms, while an unbranched aliphatic chain (as found in saturated fatty acids) is present in both the oxidized and the reduced forms. Analysis of the spin density and the highest occupied molecular orbital energy revealed that the $\mathrm{SH}$ groups exhibited the greatest electrondonating activities. The values obtained for the proton
\end{abstract}

Electronic supplementary material The online version of this article (doi:10.1007/s00894-011-1306-y) contains supplementary material, which is available to authorized users.

M. Szelag $\cdot$ D. Mikulski $\cdot$ M. Molski

Department of Theoretical Chemistry, Faculty of Chemistry,

A. Mickiewicz University,

ul. Grunwaldzka 6,

60-780 Poznań, Poland

\section{Szeląg $(\square)$}

Department of Human Molecular Genetics, Faculty of Biology,

A. Mickiewicz University,

ul. Umultowska 89,

61-614 Poznań, Poland

e-mail: grete@amu.edu.pl affinity, bond dissociation enthalpy and adiabatic ionization potential indicate that the preferred antioxidant mechanisms for $\alpha$-lipoic acid and its metabolites are sequential proton loss electron transfer in polar media and hydrogen atom transfer in vacuum.

Keywords $\alpha$-Lipoic acid · Antioxidant $\cdot$ Metabolites $\cdot$ DFT method.MP2 method.C-PCM model

\section{Introduction}

$\alpha$-Lipoic acid [LA, IUPAC: 5-(1,2-dithiolan-3-yl)-pentanoic acid; 1 in Fig. 1] is an organosulfur compound that is synthesized in small amounts by microorganisms, plants, animals, and humans [1, 2]. It is one of the most important cofactors of the multi-enzyme complexes in mitochondria. In the peptide chain, LA is covalently bound to the nitrogen atom of the lysine, forming lipoyllysine (LA-Lys; $\mathbf{5}$ in Fig. 1). Physiological demand for LA is met by its synthesis in every organism. While there is currently no record of a disease caused by LA deficiency [3], the usage of LA as a dietary supplement has recently become one of the most popular topics in the scientific and medical worlds. The largest amounts of LA-Lys can be found in the kidneys, liver, heart, and in spinach and broccoli $(\sim 1-3 \mu \mathrm{g} / \mathrm{g})$ [4].

$\alpha$-Lipoic acid was discovered by L.J. Reed during studies aimed at isolating growth-stimulating factor for Lactobacillus casei (1949-1951; note that the prefix $\alpha$ has no chemical meaning, but it is helpful in distinguishing the isolated compound from structurally related forms in biological extracts [5]). The crystallographic structure of LA was determined by Stroud and Carlisle 20 years later [6]. LA is a derivative of octanoic acid with two sulfur atoms attached to carbon atoms $\mathrm{C} 6$ and $\mathrm{C} 8$. The $\mathrm{C} 6$ atom is 
Fig. 1 Molecular structures of lipoic acid (1), the enantiomers of lipoic acid: $R-(+)-\mathrm{LA}$

(2a) and $S$-(-)-LA (2b),

dihydrolipoic acid (3), the LA/DHLA redox pair (4), and lipoyllysine (5)<smiles>O=C(O)CCCCC1[C][As]CC1</smiles>

1<smiles>[CH]1CCSS1</smiles>

$2 \mathrm{a}$<smiles>O=C(O)CCCC[C@H]1CCSS1</smiles>

$2 \mathrm{~b}$

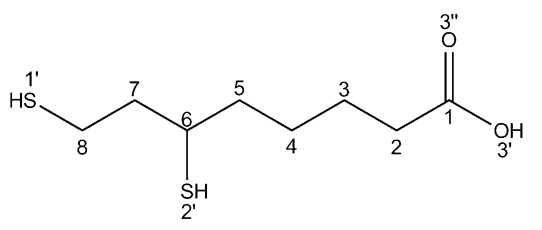<smiles>O=C(O)CCCCC(S)CCS</smiles>

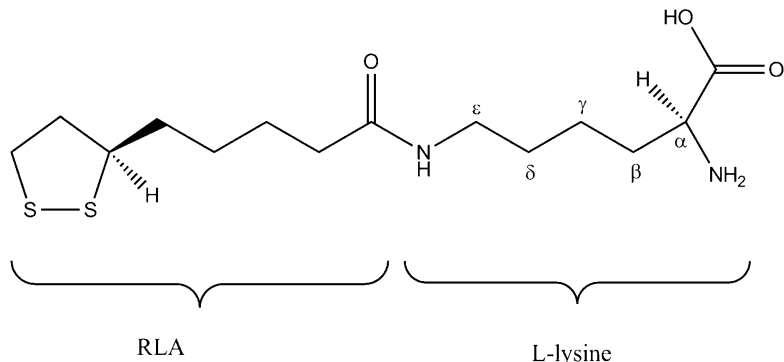

5

the chiral center of the molecule, so LA has two optical isomers - the enantiomers $R-(+)$ - and $S-(-)-(\mathbf{2 a}$ and $\mathbf{2 b}$ in Fig. 1, respectively) - and it also exists as a racemic mixture $(R / S$-LA). However, only the $R$ - $(+)$-enantiomer is synthesized by organisms and biologically active. In its oxidized form, LA has a characteristic pentatomic ring, as the two sulfur atoms are connected via a disulfide bond (S-S). The oxidized form can be reduced to an open-chain structure with two sulfhydryl groups: dihydrolipoic acid (DHLA; see 3 in Fig. 1). The redox pair LA/DHLA (4 in Fig. 1) interacts with different ROSs (reactive oxygen species), RNSs (reactive nitrogen species), as well as other oxidants and compounds with thiol groups, such as glutathione, cysteine, and $\mathrm{N}$-acetylcysteine [7-9].

RLA is a multifunctional therapeutic compound which has shown activity in many experimental in vitro and in vivo studies. RLA/RDHLA is one of the strongest natural antioxidants, and is capable of deactivating various free radicals such as the superoxide anion $\left(\mathrm{O}_{2}{ }^{-}\right)$, the hydroxyl radical $\left({ }^{\circ} \mathrm{OH}\right)$, singlet oxygen $\left({ }^{1} \mathrm{O}_{2}\right)$, peroxynitrite $\left(\mathrm{ONOO}^{-}\right)$, and hypochlorous acid $(\mathrm{HClO})$ [10-12]. It is also a very important regenerating factor for other antioxidants: thioredoxin, vitamin $\mathrm{E}$, vitamin $\mathrm{C}$, and glutathione (GSH) [13-16]. It has been proven that $\alpha$-lipoic acid 
can induce GSH synthesis [17] and act as a metal-chelating agent [18-22] and intercellular signal-transducing factor [7, 23]. RLA is viewed as a very promising therapeutic and nutritional supplement. On the basis of clinical studies, it was shown that adding RLA to the therapy reduces the symptoms of rheumatoid arthritis [7], cardiovascular diseases [24-31], diabetic polyneuropathy [32], multiple sclerosis [33-36], and Alzheimer's disease [7]. The biological and therapeutical properties of RLA are dependent on its bioavailability, tissue accumulation, and the process of metabolization [7]. RLA and RDHLA can be $\beta$-oxidized and/or S-methylated in cells [37, 38]. The most common RLA/RDHLA metabolites are presented in Fig. 2.

It is well known that free radicals can be deactivated in interactions with phenolic antioxidants via three mechanisms [39]. However, due to the similarity of $\mathrm{O}-\mathrm{H}$ and $\mathrm{S}-\mathrm{H}$ bonds, these processes can also be used to describe the antioxidant action of organosulfur compounds such as $\alpha$ lipoic acid and its metabolites (Fig. 3). We can therefore distinguish the following mechanisms of free-radical scavenging:

1. HAT (hydrogen atom transfer) mechanism:

$R S H+X \rightarrow R S+X H$

2. SPLET (sequential proton loss electron transfer) mechanism:

$R S H \rightarrow R S^{-}+H^{+}$

$R S^{-}+X^{\cdot}+H^{+} \rightarrow R S^{\cdot}+X H$<smiles>O=C(O)CC[C@H]1CCSS1</smiles>

1<smiles>O=C(O)[C@@H]1[CH]SCC1</smiles>

3<smiles>O=C(O)CCC(S)CCS</smiles>

2

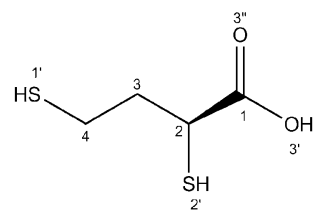

4
Fig. 2 Molecular structures of RLA/RDHLA metabolites: bisnorlipoic acid (RBLA, 1), 4,6-bisthiohexanoic acid (RDHBLA, 2), tetranorlipoic acid (STLA, 3), and 2,4-bisthiobutanoic acid (SDHTLA, 4)

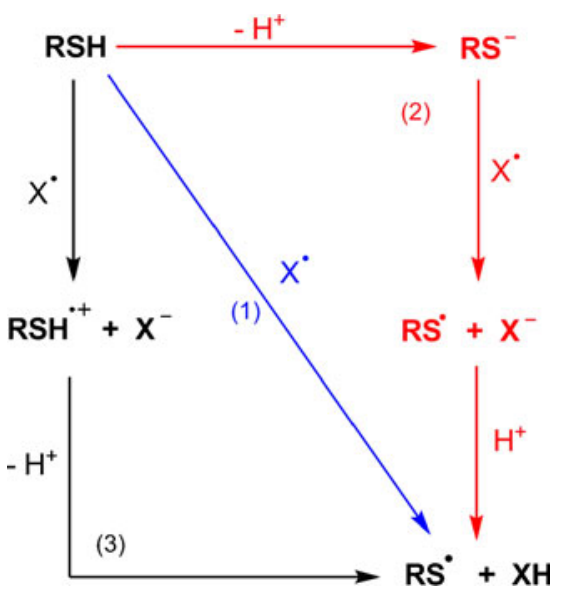

Fig. 3 Antioxidant mechanisms of organosulfur compounds: HAT (1), SPLET (2), SET-PT (3). RSH organosulfur antioxidant, $X$ free radical. From [39]

3. SET-PT (single electron transfer followed by proton transfer) mechanism:

$R S H+X \rightarrow R S H^{++}+X^{-}$

$R \mathrm{SH}^{+} \rightarrow \mathrm{RS}+\mathrm{H}^{+}$

There have been numerous publications describing experimental studies of the antioxidant properties of LA/DHLA, but this compound has not yet been investigated theoretically. In this paper, we report our detailed analysis of several of the molecular properties of LA/DHLA and RLA/RDHLA metabolites (RBLA/RDHBLA and STLA/SDHTLA), such as their molecular geometries and total molecular energies. We also describe the antioxidant properties of the compounds studied, which were derived by calculating physical antioxidant descriptors such as the adiabatic ionization potential (AIP), the bond dissociation enthalpy (BDE), the proton affinity (PA), the highest occupied molecular orbital energy $\left(E_{\mathrm{HOMO}}\right)$, and the spin density (SD) [40-44]. Because the free-radical scavenging action occurs in aqueous solution, we account for the solvating effect of water in our quantum-mechanical computations. Moreover, based on the calculations performed, we predict which of the three antioxidant mechanisms specified above is preferred for each of the compounds studied.

\section{Computational methods}

The quantum-chemical computations were performed using the Gaussian $03 \mathrm{~W}$ software package [45]. Full optimization of the geometries and energies for all of the molecules studied was carried out in the gas phase and in water 
Table 1 The bond lengths (in $\AA$ ) and angles (in degrees) of RLA [obtained using rMP2(full) $/ 6-31+(\mathrm{d}, \mathrm{p})$ and optimized in vacuum and water] along with the experimental values from the crystallographic structure of RLA [6]

\begin{tabular}{|c|c|c|c|}
\hline \multirow[t]{2}{*}{ Bond length or angle } & \multicolumn{2}{|c|}{ rMP2(full)/6-31+G(d,p) } & \multirow[t]{2}{*}{ Experiment } \\
\hline & Vacuum & Water & \\
\hline $\mathrm{C} 1-\mathrm{C} 2$ & 1.50 & 1.50 & 1.50 \\
\hline $\mathrm{C} 2-\mathrm{C} 3$ & 1.52 & 1.52 & 1.55 \\
\hline $\mathrm{C} 3-\mathrm{C} 4$ & 1.52 & 1.52 & 1.53 \\
\hline $\mathrm{C} 4-\mathrm{C} 5$ & 1.53 & 1.53 & 1.51 \\
\hline $\mathrm{C} 5-\mathrm{C} 6$ & 1.52 & 1.52 & 1.53 \\
\hline $\mathrm{C} 6-\mathrm{C} 7$ & 1.54 & 1.54 & 1.55 \\
\hline $\mathrm{C} 7-\mathrm{C} 8$ & 1.54 & 1.54 & 1.51 \\
\hline $\mathrm{S} 1^{\prime}-\mathrm{C} 8$ & 1.82 & 1.82 & 1.79 \\
\hline $\mathrm{S} 2{ }^{\prime}-\mathrm{C} 6$ & 1.82 & 1.83 & 1.83 \\
\hline $\mathrm{S} 1^{\prime}-\mathrm{S} 2^{\prime}$ & 2.07 & 2.08 & 2.05 \\
\hline $\mathrm{O} 3^{\prime}-\mathrm{C} 1$ & 1.36 & 1.36 & 1.31 \\
\hline $\mathrm{O} 3^{\prime \prime}-\mathrm{C} 1$ & 1.22 & 1.22 & 1.20 \\
\hline $\mathrm{C} 1-\mathrm{C} 2-\mathrm{C} 3$ & 113.02 & 113.46 & 112.99 \\
\hline $\mathrm{C} 2-\mathrm{C} 3-\mathrm{C} 4$ & 111.92 & 111.70 & 110.39 \\
\hline $\mathrm{C} 3-\mathrm{C} 4-\mathrm{C} 5$ & 112.17 & 111.93 & 109.28 \\
\hline $\mathrm{C} 4-\mathrm{C} 5-\mathrm{C} 6$ & 112.46 & 112.18 & 115.38 \\
\hline $\mathrm{C} 5-\mathrm{C} 6-\mathrm{C} 7$ & 113.48 & 113.56 & 112.89 \\
\hline $\mathrm{C} 6-\mathrm{C} 7-\mathrm{C} 8$ & 111.86 & 112.29 & 112.61 \\
\hline $\mathrm{C} 7-\mathrm{C} 8-\mathrm{S} 1^{\prime}$ & 109.26 & 109.36 & 112.61 \\
\hline $\mathrm{C} 8-\mathrm{S} 1^{\prime}-\mathrm{S} 2^{\prime}$ & 90.22 & 109.36 & 95.56 \\
\hline $\mathrm{C} 6-\mathrm{S} 2^{\prime}-\mathrm{S} 1^{\prime}$ & 90.63 & 90.97 & 92.84 \\
\hline C5-C6-S2' & 110.46 & 110.27 & 111.37 \\
\hline C7-C6-S2' & 108.17 & 108.28 & 106.76 \\
\hline $\mathrm{O} 3^{\prime}-\mathrm{C} 1-\mathrm{C} 2$ & 111.24 & 111.50 & 113.39 \\
\hline $\mathrm{O} 3 "-\mathrm{C} 1-\mathrm{C} 2$ & 126.16 & 126.09 & 124.89 \\
\hline $\mathrm{O} 3^{\prime}-\mathrm{C} 1-\mathrm{O} 3^{\prime \prime}$ & 122.60 & 122.41 & 121.89 \\
\hline
\end{tabular}

without symmetry constraints. The geometries of the neutral compounds in their ground states were optimized using DFT with the restricted rB3LYP hybrid functional [46-48] combined with the 6-311+G(3df,2p) and aug-ccpVDZ basis sets. The geometry optimization of mono-, di-, and trianions was carried out with the rB3LYP/6-311+G (df,2p) method. To optimize the radicals and cation radicals, the unrestricted $\mathrm{uB} 3 \mathrm{LYP} / 6-311+\mathrm{G}(3 \mathrm{df}, 2 \mathrm{p})$ level of theory was applied, since it gives the best results for open-shell molecular systems. Additionally, the neutral forms of LA and DHLA enantiomers were optimized using second-order Møller-Plesset perturbation theory [49] combined with the $6-31+\mathrm{G}(\mathrm{d}, \mathrm{p})$ basis set in vacuum and water. rMP2(full) $/ 6-31+\mathrm{G}(\mathrm{d}, \mathrm{p})$ was applied to achieve a better description of electron correlation effects in the compounds studied. Aside from analyzing the geometries, the single point energies for RLA and SLA were calculated using
DFT and MP2(full) methods combined with a wide spectrum of basis sets $[6-31 \mathrm{G}(\mathrm{d}, \mathrm{p}), 6-31+\mathrm{G}(\mathrm{d}, \mathrm{p}), 6-31++\mathrm{G}$ (d,p), 6-311G(d,p), 6-311+G(d,p), 6-311++G(d,p), 6-31G (3df,2p), 6-31+G(3df,2p), 6-31++G(3df,2p), 6-311G (3df,2p), 6-311+G(3df,2p), 6-311++G(3df,2p), cc-pVDZ, cc-pVTZ, cc-pVQZ, aug-cc-pVDZ, and aug-cc-pVTZ] in order to compare the energies of stereoisomers.

To establish the starting geometries of the compounds studied and the locations of the structures with minimum energy, a conformational analysis was performed. Rotational potential energy profiles at $\mathrm{rHF} / 6-31+\mathrm{G}(\mathrm{d}, \mathrm{p})$ for RLA, RDHLA, SLA, and SDHLA were constructed by scanning the internal dihedral angles $\left(\alpha=\mathrm{C}_{1}-\mathrm{C}_{2}-\mathrm{C}_{3}-\mathrm{C}_{4}\right.$ and $\beta=\mathrm{C}_{3}-\mathrm{C}_{4}-\mathrm{C}_{5}-\mathrm{C}_{6}$ for LA, $\alpha=\mathrm{C}_{1}-\mathrm{C}_{2}-\mathrm{C}_{3}-\mathrm{C}_{4}$ and $\gamma=\mathrm{C}_{6}-\mathrm{C}_{7}-$ $\mathrm{C}_{8}-\mathrm{S}_{1}{ }^{\prime}$ for DHLA) over the ranges $180^{\circ} \leq \alpha \leq 360^{\circ}$, $180^{\circ} \leq \beta \leq 360^{\circ}, 180^{\circ} \leq \gamma \leq 360^{\circ}$, with no constraint placed on any other geometric parameter (see the "Electronic supplementary material," ESM). In the next step, the most stable structures obtained from the scan were fully optimized around each potential minimum without symmetry constraints. For all of the optimized structures, harmonic vibrational frequencies were calculated in order to verify the stationary points on the potential energy surfaces (PES).

The antioxidant properties of the molecules studied were described by calculating the numerical parameters (at 298 K) associated with their antioxidant mechanisms

Table 2 The bond lengths (in $\AA$ ) and angles (in degrees) of RLA and SLA [obtained using rMP2(full)/6-31+(d,p) and optimized in vacuum and water]

\begin{tabular}{|c|c|c|c|c|}
\hline \multirow[t]{3}{*}{ Bond length or angle } & \multicolumn{4}{|c|}{ rMP2(full)/6-31+G(d,p) } \\
\hline & \multicolumn{2}{|c|}{ Vacuum } & \multicolumn{2}{|l|}{ Water } \\
\hline & RLA & SLA & RLA & SLA \\
\hline $\mathrm{C} 6-\mathrm{C} 7$ & 1.54 & 1.54 & 1.54 & 1.54 \\
\hline $\mathrm{C} 7-\mathrm{C} 8$ & 1.54 & 1.54 & 1.54 & 1.54 \\
\hline $\mathrm{S} 1^{\prime}-\mathrm{C} 8$ & 1.82 & 1.82 & 1.82 & 1.82 \\
\hline $\mathrm{S} 2^{\prime}-\mathrm{C} 6$ & 1.82 & 1.83 & 1.83 & 1.83 \\
\hline $\mathrm{S} 1^{\prime}-\mathrm{S} 2^{\prime}$ & 2.07 & 2.07 & 2.08 & 2.08 \\
\hline $\mathrm{O} 3^{\prime}-\mathrm{C} 1$ & 1.36 & 1.36 & 1.36 & 1.36 \\
\hline $\mathrm{O} 3 "-\mathrm{C} 1$ & 1.22 & 1.22 & 1.22 & 1.22 \\
\hline $\mathrm{C} 6-\mathrm{C} 7-\mathrm{C} 8$ & 111.86 & 111.95 & 112.29 & 112.38 \\
\hline $\mathrm{C} 7-\mathrm{C} 8-\mathrm{S} 1^{\prime}$ & 109.26 & 109.41 & 109.36 & 109.72 \\
\hline $\mathrm{C} 8-\mathrm{S} 1^{\prime}-\mathrm{S} 2^{\prime}$ & 90.22 & 90.75 & 90.60 & 91.65 \\
\hline $\mathrm{S} 1^{\prime}-\mathrm{S} 2^{\prime}-\mathrm{C} 6$ & 90.63 & 90.25 & 90.97 & 90.29 \\
\hline $\mathrm{S} 2{ }^{\prime}-\mathrm{C} 6-\mathrm{C} 7$ & 108.17 & 107.91 & 108.28 & 107.59 \\
\hline $\mathrm{C} 1-\mathrm{C} 2-\mathrm{C} 3-\mathrm{C} 4$ & 179.47 & 179.99 & 179.97 & 179.77 \\
\hline $\mathrm{C} 3-\mathrm{C} 4-\mathrm{C} 5-\mathrm{C} 6$ & 177.65 & 172.96 & 177.37 & 172.53 \\
\hline $\mathrm{C} 8-\mathrm{S} 1^{\prime}-\mathrm{S} 2^{\prime}-\mathrm{C} 6$ & 46.99 & 46.76 & 46.02 & 45.35 \\
\hline
\end{tabular}


Table 3 The bond lengths (in $\AA$ ) and angles (in degrees) of RDHLA and SDHLA [obtained using rMP2(full)/6-31+(d,p) and optimized in vacuum and water]

\begin{tabular}{|c|c|c|c|c|}
\hline \multirow[t]{3}{*}{ Bond length or angle } & \multicolumn{4}{|c|}{ rMP2(full)/6-31+G(d,p) } \\
\hline & \multicolumn{2}{|l|}{ Vacuum } & \multicolumn{2}{|l|}{ Water } \\
\hline & RDHLA & SDHLA & RDHLA & SDHLA \\
\hline C6-C7 & 1.53 & 1.53 & 1.53 & 1.53 \\
\hline $\mathrm{C} 7-\mathrm{C} 8$ & 1.52 & 1.52 & 1.52 & 1.52 \\
\hline $\mathrm{S} 1^{\prime}-\mathrm{C} 8$ & 1.83 & 1.82 & 1.83 & 1.82 \\
\hline $\mathrm{S} 1^{\prime}-\mathrm{H} 1^{\prime}$ & 1.33 & 1.33 & 1.33 & 1.33 \\
\hline $\mathrm{S} 2^{\prime}-\mathrm{C} 6$ & 1.83 & 1.83 & 1.83 & 1.83 \\
\hline $\mathrm{S} 2^{\prime}-\mathrm{H} 2^{\prime}$ & 1.33 & 1.33 & 1.33 & 1.33 \\
\hline $\mathrm{O} 3^{\prime}-\mathrm{C} 1$ & 1.36 & 1.36 & 1.36 & 1.36 \\
\hline $\mathrm{O} 3 "-\mathrm{C} 1$ & 1.22 & 1.22 & 1.22 & 1.22 \\
\hline $\mathrm{C} 7-\mathrm{C} 8-\mathrm{S} 1^{\prime}$ & 110.06 & 108.79 & 110.37 & 108.93 \\
\hline $\mathrm{C} 7-\mathrm{C} 6-\mathrm{S} 2^{\prime}$ & 112.73 & 112.94 & 112.74 & 112.78 \\
\hline $\mathrm{C} 6-\mathrm{C} 7-\mathrm{C} 8$ & 116.05 & 114.00 & 116.34 & 113.88 \\
\hline $\mathrm{C} 1-\mathrm{C} 2-\mathrm{C} 3-\mathrm{C} 4$ & 179.97 & 179.86 & 179.90 & 179.71 \\
\hline $\mathrm{C} 5-\mathrm{C} 6-\mathrm{C} 7-\mathrm{C} 8$ & 176.62 & 175.94 & 177.79 & 174.01 \\
\hline
\end{tabular}

(described above), such as their proton affinities (PA; the SPLET mechanism), bond dissociation enthalpies (BDE; the HAT mechanism), and adiabatic ionization potentials (AIP; SET-PT mechanism) [50-55]:

$P A=H_{\mathrm{a}}+H_{\mathrm{p}}-H_{\mathrm{m}}$,

where $H_{\mathrm{a}}$ is the enthalpy of the anion, $H_{\mathrm{p}}$ is the enthalpy of the proton, and $H_{\mathrm{m}}$ is the enthalpy of the parent molecule;

$B D E=H_{\mathrm{r}}+H_{\mathrm{H}}-H_{\mathrm{m}}$,

where $H_{\mathrm{r}}$ is the enthalpy of the radical, $H_{\mathrm{H}}$ is the enthalpy of the $\mathrm{H}$ atom, and $H_{\mathrm{m}}$ is the enthalpy of the parent molecule; and

$A I P=E_{\mathrm{cr}}-E_{\mathrm{m}}$,
Table 4 The total energy values [in Ha] of RLA and SLA [obtained using rMP2(full) and optimized in vacuum]. $\Delta E_{\text {total }}$ (in $\mathrm{kcal} \mathrm{mol}^{-1}$ ) of RLA and SLA

\begin{tabular}{llll}
\hline Basis set & \multicolumn{2}{l}{ MP2(full) } & \\
\cline { 2 - 4 } & RLA & SLA & $\Delta E_{\text {total }}$ \\
\hline 6-31G(3df,2p) & -1258.253 & -1258.253 & 0.305 \\
6-31+G(3df,2p) & -1258.275 & -1258.275 & 0.226 \\
6-31++G(3df,2p) & -1258.276 & -1258.277 & 0.282 \\
6-311++G(3df,2p) & -1258.810 & -1258.811 & 0.526 \\
cc-pVDZ & -1257.728 & -1257.728 & 0.447 \\
cc-pVTZ & -1258.507 & -1258.507 & 0.498 \\
cc-pVQZ & -1258.877 & -1258.878 & 0.543 \\
aug-cc-pVDZ & -1257.861 & -1257.861 & 0.369 \\
aug-cc-pVTZ & -1258.597 & -1258.597 & 0.474 \\
\hline
\end{tabular}

where $E_{\mathrm{cr}}$ is the total energy of the cation radical, and $E_{\mathrm{m}}$ is the total energy of the parent molecule.

In the calculations, the following enthalpy values were used: $H\left(\mathrm{H}^{*}\right)_{\text {vacuum }}=-0.49764 \mathrm{Ha}$ (i.e. hartrees), [42], $\Delta_{\text {hydr }} H\left(\mathrm{H}^{*}\right)=-0.00152 \mathrm{Ha}[56,57] ; H\left(\mathrm{H}^{+}\right)_{\text {vacuum }}=0.00236$ Ha [40]; $\Delta_{\text {hydr }} H\left(\mathrm{H}^{+}\right)=-0.41516 \mathrm{Ha}[58]$.

Additional parameters describing the electron-donating properties of the compounds studied (the HOMO orbital distribution and the spin density distribution) were calculated at the B3LYP/6-311+G(3df,2p) level of theory in vacuum and in water.

The optimizations of all forms of the compounds investigated and the calculations of the antioxidant parameters in water were performed using the C-PCM solvation model (conductor-like polarizable continuum model), [59]. In the calculations, a dielectric constant of 78.39 was used for water. This approach was employed and described in our previous works on the antioxidant properties of phenolic compounds (trans-resveratrol and its derivatives) [41, 60-62].

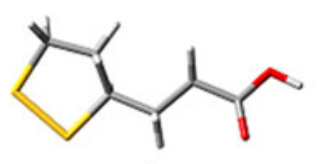

1

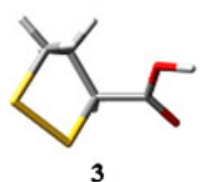

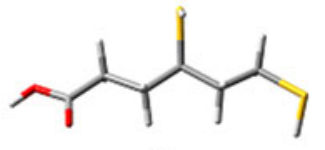

2

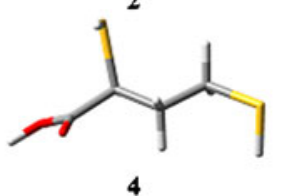

Fig. 5 The geometries of RLA/RDHLA metabolites [obtained using rB3LYP/6-311+G(3df,2p) and optimized in water]: RBLA (1), RDHBLA (2), STLA (3), and SDHTLA (4)
Fig. 4 The geometries of RLA (1), RDHLA (2), SLA (3), and SDHLA (4) [obtained using rMP2(full)/6-31+(d,p) and optimized in water] 
Table 5 The AIP (in $\mathrm{kcal} \mathrm{mol}^{-1}$ ) and $\triangle \mathrm{AIP}$ (in $\mathrm{kcal} \mathrm{mol}^{-1}$ ) values [calculated at the B3LYP/6-311+G(3df,2p) level in vacuum and water] of LA/DHLA enantiomers and RLA/RDHLA metabolites

\begin{tabular}{|c|c|c|c|c|}
\hline \multirow[t]{2}{*}{ Compound } & \multicolumn{2}{|l|}{ Vacuum } & \multicolumn{2}{|l|}{ Water } \\
\hline & AIP (kcal/mol) & $\Delta \mathrm{AIP}(\mathrm{kcal} / \mathrm{mol})$ & AIP (kcal/mol) & $\Delta \mathrm{AIP}(\mathrm{kcal} / \mathrm{mol})$ \\
\hline RLA & 171 & 0 & 131 & 0 \\
\hline SLA & 171 & 0 & 131 & 0 \\
\hline RDHLA & 193 & 22 & 159 & 28 \\
\hline SDHLA & 191 & 21 & 157 & 26 \\
\hline RBLA & 173 & 2 & 132 & 1 \\
\hline RDHBLA & 195 & 24 & 158 & 27 \\
\hline STLA & 193 & 22 & 128 & -3 \\
\hline SDHTLA & 199 & 28 & 162 & 31 \\
\hline
\end{tabular}

\section{Results and discussion}

The optimized geometries of LA and DHLA enantiomers

Optimizing all of the compounds' geometries at the rB3LYP/6-311+G(3df,2p), rB3LYP/aug-cc-pVDZ, and rMP2(full) $/ 6-31+(\mathrm{d}, \mathrm{p})$ levels of theory leads to the absolute energy minima on the potential energy surface, which is confirmed by the absence of imaginary frequencies. The bond lengths (in $\AA$ ) and the angles (in degrees) of the equilibrium optimized neutral structure of RLA in comparison and the corresponding experimental crystallographic data are summarized in Table 1 and Table S1 of the ESM. It should be pointed out, that regardless of the method and basis set used, the equilibrium values of geometrical parameters are almost identical and very similar to the results obtained by Stroud and Carlisle (1972) for the crystallographic structure of LA [6]. Additionally, the results presented in Tables 2 and 3 and Tables S2 and S3 of the ESM reveal that there are no geometric differences between enantiomers (RLA and SLA; RDHLA and SDHLA, see Fig. 4), which is in good agreement with the statement that optical isomers are like mirror images of each other. The analysis of $\Delta E_{\text {total }}$ for RLA and SLA, as calculated using DFT and MP2(full) employing a wide range of basis sets (Table 4 and Table S4 of the ESM), confirms that the enantiomers are isoenergetic structures.

\section{The optimized geometries of RLA/RDHLA metabolites}

Optimization of the geometries of the metabolites was performed at the $\mathrm{rB} 3 \mathrm{LYP} / 6-311+\mathrm{G}(3 \mathrm{df}, 2 \mathrm{p})$ level of theory in vacuum and water. The equilibrium geometries (Fig. 5) are at the absolute energy minima on the potential energy surface, as confirmed by the absence of imaginary frequencies. A comparative analysis of the geometrical parameters in vacuum (Table S5 of the ESM) and in water (Table S6 of the ESM) reveals that there is good agreement between the molecular structures of RLA, RDHLA, and their metabolites. All of the compounds studied demonstrate similarities in the geometry of the aliphatic chain. The values of the dihedral angle $\mathrm{C}_{*}-\mathrm{S}_{1}{ }^{\prime}-\mathrm{S}_{2}{ }^{\prime}-\mathrm{C}_{*}$ in the cyclic forms (where $\mathrm{C}_{*}$ has a different number in each cyclic form) indicate that the pentatomic ring is not a planar system but has the conformation of an envelope. The $1^{\prime}-\mathrm{S}-\mathrm{H}$ and 2 '-S-H bond lengths of the reduced forms are practically identical in both vacuum and water, which indicates a lack of influence of solvation effects.
Table 6 The BDE (in $\mathrm{kcal} \mathrm{mol}{ }^{-1}$ ) and $\triangle \mathrm{BDE}$ (in $\mathrm{kcal} \mathrm{mol}^{-1}$ ) values [calculated at the B3LYP/6-311+G(3df,2p) level in vacuum and water] of RDHLA, SDHLA, RDHBLA, and SDHTLA

\begin{tabular}{llllll}
\hline \multirow{2}{*}{ Bond } & \multicolumn{2}{l}{ Vacuum } & & Water \\
\cline { 2 - 3 } \cline { 5 - 6 } \cline { 5 - 6 } & BDE (in kcal/mol) & $\Delta$ BDE (in kcal/mol) & & BDE (in kcal/mol) & $\begin{array}{l}\Delta \text { BDE } \\
\text { (in kcal/mol) }\end{array}$ \\
\hline 1'-SH-RDHBLA & 86 & 1 & 96 & 1 \\
1'-SH-RDHLA & 85 & 0 & 96 & 0 \\
1'-SH-SDHLA & 85 & 0 & 95 & 0 \\
1'-SH-SDHTLA & 85 & 1 & 96 & 1 \\
2'-SH-RDHBLA & 85 & 1 & 97 & 1 \\
2'-SH-RDHLA & 86 & 1 & 96 & 2 \\
2'-SH-SDHLA & 86 & 2 & 97 & 2 \\
2'-SH-SDHTLA & 87 & 2 & 97 & 2 \\
\hline
\end{tabular}


Table 7 The PA (in kcal mol ${ }^{-1}$ ) and $\triangle \mathrm{PA}$ (in $\mathrm{kcal} \mathrm{mol}^{-1}$ ) values [calculated at the rB3LYP/6-311+ $\mathrm{G}(3 \mathrm{df}, 2 \mathrm{p})$ level in vacuum and water] of the neutral, mono-, and dianionic forms of RDHLA and its metabolites

\begin{tabular}{|c|c|c|c|c|c|c|c|c|}
\hline \multirow[t]{3}{*}{ Compound } & \multicolumn{4}{|c|}{ 1'-S-H } & \multicolumn{4}{|c|}{$2^{\prime}-\mathrm{S}-\mathrm{H}$} \\
\hline & \multicolumn{2}{|c|}{ Vacuum } & \multicolumn{2}{|c|}{ Water } & \multicolumn{2}{|c|}{ Vacuum } & \multicolumn{2}{|c|}{ Water } \\
\hline & $\mathrm{PA}$ & $\Delta \mathrm{PA}$ & PA & $\Delta \mathrm{PA}$ & $\mathrm{PA}$ & $\Delta \mathrm{PA}$ & PA & $\Delta \mathrm{PA}$ \\
\hline RDHLA & 344 & 0 & 34 & 0 & 342 & 0 & 44 & 0 \\
\hline RDHBLA & 350 & 6 & 23 & -11 & 341 & -1 & 32 & -11 \\
\hline SDHTLA & 349 & 4 & 33 & 0 & 339 & -3 & 29 & -15 \\
\hline 3'-O-mRDHLA & 384 & 40 & 34 & 0 & 388 & 46 & 34 & -10 \\
\hline 3'-O-mRDHBLA & 398 & 53 & 25 & -8 & 408 & 66 & 26 & -17 \\
\hline 3'-O-mSDHTLA & 414 & 70 & 27 & -7 & 434 & 92 & 28 & -16 \\
\hline $2^{\prime}-\mathrm{S}, 3^{\prime}-\mathrm{O}-\mathrm{dRDHLA}$ & 458 & 113 & 36 & 2 & - & - & - & - \\
\hline $1^{\prime}-\mathrm{S}, 3^{\prime}-\mathrm{O}-\mathrm{dRDHLA}$ & - & - & - & - & 461 & 120 & 37 & -7 \\
\hline 2'-S,3'-O-dRDHBLA & 466 & 122 & 37 & 3 & - & - & - & - \\
\hline 1'-S,3'-O-dRDHBLA & - & - & - & - & 476 & 135 & 38 & -6 \\
\hline 2'-S,3'-O-dSDHTLA & 481 & 137 & 37 & 3 & - & - & - & - \\
\hline 1'-S,3'-O-dSDHTLA & - & - & - & - & 501 & 160 & 38 & -6 \\
\hline
\end{tabular}

AIP, BDE, PA, spin density, and HOMO orbital distribution

AIP is a very important physical property that describes the process of single electron donation by the antioxidant. The smaller the AIP value, the greater the chance that ionization will occur. Molecules with low AIP values are considered very good antioxidants. Calculations (Table 5) indicate that the lowest values of AIP in both vacuum and water media are associated with oxidized forms: RLA, RBLA, STLA (in order of increasing AIP) in vacuum and STLA, RLA, RBLA (in order of increasing AIP) in water. In vacuum, the same order can be ascribed to the reduced forms: RDHLA, RDHBLA, SDHTLA, but in water, we observe the following growing order: RDHBLA, RDHLA, SDHTLA. The AIP values in water are lower than in vacuum for all of the compounds studied. This is connected to the strong electrostatic interaction of the polar medium with cation radical forms. Because AIP represents the SET-PT mechanism, it is possible that this mechanism is more preferable in water than in vacuum.
The stability of the $\mathrm{S}-\mathrm{H}$ bond can be evaluated using a thermodynamic parameter, the homolytic BDE. Hydrogen atom transfer from antioxidant to radical is a possible antioxidant mechanism. Because the reduced forms of the compounds studied have two $\mathrm{S}-\mathrm{H}$ bonds, we have taken into consideration all possible reactions. The calculated values of the BDE are presented in Table 6. Based on the results obtained, it is clear that RDHLA and its metabolites have similar $\mathrm{S}-\mathrm{H}$ bond stabilities. Just as for the AIP results (Table 5), there are no differences between the DHLA stereoisomers in vacuum and in water. In water, the $\mathrm{S}-\mathrm{H}$ bond is less prone to homolytic fission than in vacuum, because of higher BDE values. This means that the HAT mechanism is not preferable in a polar medium for the compounds studied. Hydrogen atom transfer is hindered because a polar medium increases the stability of $\mathrm{S}-\mathrm{H}$ bonds.

The PA values were calculated for the neutral forms of RDHLA, RDHBLA, and SDHTLA, as well as for their 3'-
Table 8 The spin density (SD) values [calculated at the uB3LYP/6-311+G(3df,2p) level in vacuum and water] of RDHLA, SDHLA, RDHBLA, and SDHTLA radicals

\begin{tabular}{|c|c|c|c|c|c|c|c|c|}
\hline \multirow[t]{2}{*}{ Radical } & \multicolumn{4}{|l|}{ Vacuum } & \multicolumn{4}{|l|}{ Water } \\
\hline & $\mathrm{S} 1^{\prime}$ & $\mathrm{S} 2^{\prime}$ & O3' & O3" & $\mathrm{S} 1^{\prime}$ & $\mathrm{S} 2^{\prime}$ & O3' & O3" \\
\hline 1'-S-RDHBLA & 1.0662 & 0.0137 & -0.0002 & 0.0000 & 1.0700 & 0.0149 & -0.0002 & 0.0000 \\
\hline 1'-S-RDHLA & 1.0487 & 0.0033 & 0.0000 & 0.0000 & 1.0642 & 0.0045 & 0.0000 & 0.0000 \\
\hline 1'-S-SDHLA & 1.0796 & 0.0084 & 0.0000 & 0.0000 & 1.0830 & 0.0080 & 0.0000 & 0.0000 \\
\hline 1'-S-SDHTLA & 1.0522 & 0.0116 & -0.0001 & 0.0001 & 1.0569 & 0.0110 & -0.0002 & 0.0000 \\
\hline 2'-S-RDHBLA & -0.0042 & 1.0496 & 0.0002 & 0.0000 & -0.0064 & 1.0540 & 0.0002 & -0.0001 \\
\hline $2^{\prime}$-S-RDHLA & 0.0041 & 1.0611 & 0.0000 & 0.0001 & 0.0032 & 1.0693 & 0.0001 & 0.0001 \\
\hline $2^{\prime}$-S-SDHLA & -0.0088 & 1.0560 & 0.0000 & 0.0001 & 0.0163 & 1.0397 & 0.0001 & 0.0003 \\
\hline 2'-S-SDHTLA & 0.0011 & 1.0313 & 0.0031 & 0.0147 & 0.0005 & 1.0349 & 0.0024 & 0.0130 \\
\hline
\end{tabular}


O-monoanions, 1'-S,3'-O-dianions, and 2'-S,3'-O-dianions. The results obtained are presented in Table 7. For all of the compounds studied, the PA values in water are much smaller than those in vacuum, which means that in a polar medium the SPLET mechanism is greatly preferred. Turning our attention to the $\triangle \mathrm{PA}$ values, we notice that $\mathrm{S}-\mathrm{H}$ bonds in the monoanions and dianions are more prone to heterolytic fission than those in neutral forms. The higher PA values observed for the 2'-S-H bond than for the 1'-S-H bond suggest that the former break more easily.

Upon comparing the AIP, PA, and BDE values for all of the compounds studied, it is clear that the preferred antioxidant pathway in a polar medium for lipoic acid and its metabolites is the SPLET mechanism. The HAT mechanism is preferred in nonpolar media.

When describing the free-radical scavenging activities of molecules, parameters such as the spin density (SD) distribution in free radicals and the energy of the HOMO orbital are also useful. The SD has been calculated for the 1'-S- and 2'-S-radicals of RDHLA, SDHLA, RDHBLA, and SDHTLA. According to these calculations (Table 8), the highest concentration of SD is observed for the $\mathrm{S}_{1}{ }^{\prime}$ atom in $1^{\prime}$-S-radicals and for $\mathrm{S}_{2}{ }^{\prime}$ in $2^{\prime}$-S-radicals. In comparison, the $\mathrm{SD}$ values for the $\mathrm{O}_{3}{ }^{\prime}$ and $\mathrm{O}_{3}{ }^{\prime \prime}$ atoms in these radicals are very small, which proves the absence of electron delocalization through the whole molecule. The SD values in water are slightly higher than those in vacuum for all of the radicals studied (Table 8). We can therefore conclude that the antioxidant mechanisms involving radical action are not preferred in polar media. The energy of the HOMO orbital is another important molecular parameter associated with the scavenging of free radicals. Molecules with higher $E_{\mathrm{HOMO}}$ values have stronger electron-donating abilities. All of the compounds studied have similar values of $E_{\text {НОмО }}$ (Table 9). The electronic density distribution in these orbitals is concentrated on the sulfur atoms (Fig. 6). Similar to the SD distribution, there is no delocalization of HOMO

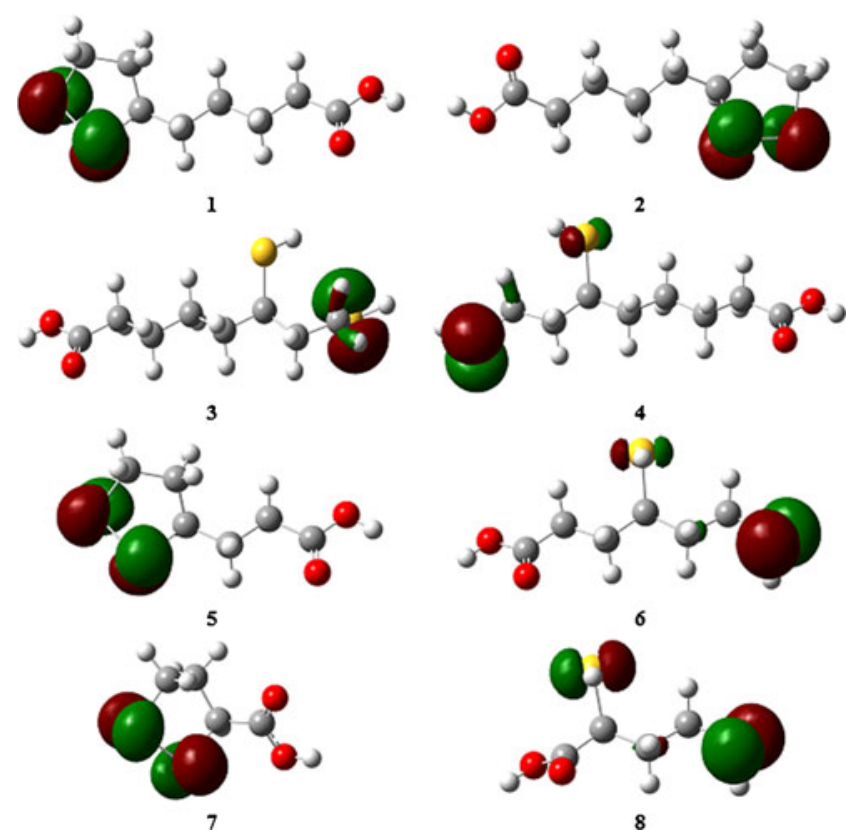

Fig. 6 The HOMO orbital distributions in RLA (1), SLA (2), RDHLA (3), SDHLA (4), RBLA (5), RDHBLA (6), STLA (7), and SDHTLA (8). The calculations were accomplished in vacuum with the isovalue 0.07

orbitals. It can be predicted that $\mathrm{S}-\mathrm{S}$ and $\mathrm{S}-\mathrm{H}$ bonds are the most probable sites of free-radical attack in all of the molecules studied.

\section{Conclusions}

Structure-antioxidant parameter relationships of $\alpha$-lipoic acid and its natural metabolites bisnorlipoic acid and tetranorlipoic acid in their oxidized and reduced forms have been investigated using quantum-chemical methods: DFT/B3LYP and MP2(full). On the basis of the results obtained, we can confirm that the SH groups of the reduced

Table 9 The HOMO orbital distributions ( $E_{\mathrm{HOMO}}$ and $\left.\Delta E_{\mathrm{HOMO}}\right)$ of LA/DHLA enantiomers and RLA/RDHLA metabolites [obtained using $\mathrm{rB} 3 \mathrm{LYP} / 6-311+\mathrm{G}(3 \mathrm{df}, 2 \mathrm{p})$ and optimized in vacuum and water]

\begin{tabular}{|c|c|c|c|c|c|c|}
\hline \multirow[t]{2}{*}{ Compounds } & \multicolumn{3}{|l|}{ Vacuum } & \multicolumn{3}{|l|}{ Water } \\
\hline & $E_{\text {Номо }}(\mathrm{Ha})$ & $E_{\text {Номо }}(\mathrm{eV})$ & $\Delta E_{\text {Номо }}(\mathrm{eV})$ & $E_{\text {Номо }}(\mathrm{Ha})$ & $E_{\text {номо }}(\mathrm{eV})$ & $\Delta E_{\text {номо }}(\mathrm{eV})$ \\
\hline RLA & -0.215 & -5.9 & 0.0 & -0.211 & -5.7 & 0.0 \\
\hline SLA & -0.214 & -5.8 & 0.0 & -0.212 & -5.8 & 0.0 \\
\hline RDHLA & -0.245 & -6.7 & 0.8 & -0.240 & -6.5 & 0.8 \\
\hline SDHLA & -0.244 & -6.6 & 0.8 & -0.241 & -6.5 & 0.8 \\
\hline RBLA & -0.218 & -5.9 & 0.1 & -0.212 & -5.8 & 0.0 \\
\hline RDHBLA & -0.246 & -6.7 & 0.8 & -0.247 & -6.7 & 1.0 \\
\hline STLA & -0.220 & -6.0 & 0.1 & -0.220 & -6.0 & 0.3 \\
\hline SDHTLA & -0.249 & -6.8 & 0.9 & -0.246 & -6.7 & 0.9 \\
\hline
\end{tabular}


forms are responsible for their antioxidant properties. More importantly, we propose that the most preferable antioxidant mechanism in polar media is SPLET. However, in nonpolar media, the HAT mechanism is preferred, as shown by calculations performed for isolated molecules. $\alpha$-Lipoic acid and its natural metabolites are not the only available organosulfur acids that act as antioxidants; LA/DHLA derivatives should also be included in quantum-chemical investigations.

Acknowledgments The calculations were performed at the Poznan Supercomputing and Networking Center (PCSS). The authors are grateful for grant no. 76, "Theoretical study of lipoic acid and its biological activity."

Open Access This article is distributed under the terms of the Creative Commons Attribution Noncommercial License which permits any noncommercial use, distribution, and reproduction in any medium, provided the original author(s) and source are credited.

\section{References}

1. Carreau JP (1979) Biosynthesis of lipoic acid via unsaturated fatty acids. Methods Enzymol 62:152-158

2. Reed LJ (2001) A trail of research from lipoic acid to alpha-keto acid dehydrogenase complexes. J Biol Chem 276:38329-38336

3. Biewenga GP, Haenen GR, Bast A (1997) The pharmacology of the antioxidant lipoic acid. Gen Pharmacol 29:315-331

4. Lodge JK, Youn HD, Handelman GJ, Konishi T, Matsugo S, Mathur VV, Packer L (1997) Natural sources of lipoic acid: determination of lipoyllysine released from protease-digested tissues by high performance liquid chromatography incorporating electrochemical detection. J Appl Nutr 49:3-11

5. Reed LJ, DeBusk BG, Gunsalus IC, Hornberger CS (1951) Crystalline $\alpha$-lipoic acid: a catalytic agent associated with pyruvate dehydrogenase. Science 114:93-94

6. Stroud RM, Carlisle CH (1972) Single-crystal structure determination of DL-6-thioctic acid, $\mathrm{C}_{8} \mathrm{H}_{14} \mathrm{O}_{2} \mathrm{~S}_{2}$. Acta Crystallogr B 28:304-307

7. Shay KP, Moreau RF, Smith EJ, Smith AR, Hagen TM (2009) Alpha-lipoic acid as a dietary supplement: molecular mechanisms and therapeutic potential. Biochim Biophys Acta 1790:1149-1160

8. Aruoma OI, Halliwell B, Hoey BM, Butler J (1989) The antioxidant action of $\mathrm{N}$-acetylcysteine: its reaction with hydrogen peroxide, hydroxyl radical, superoxide, and hypochlorous acid. Free Rad Biol Med 6:593-597

9. Agnihotri N, Mishra PC (2009) Mechanism of scavenging action of $\mathrm{N}$-acetylcysteine for the $\mathrm{OH}$ radical: a quantum computational study. J Phys Chem B 113:12096-12104

10. Suzuki YJ, Tsuchiya M, Packer L (1991) Thioctic acid and dihydrolipoic acid are novel antioxidants which interact with reactive oxygen species. Free Radic Res Commun 15:255-263

11. Devasagayam TP, Di Mascio P, Kaiser S, Sies H (1991) Singlet oxygen induced singlestrand breaks in plasmid pBR322 DNA: the enhancing effect of thiols. Biochim Biophys Acta 1088:409-412

12. Haenen GR, Bast A (1991) Scavenging of hypochlorous acid by lipoic acid. Biochem Pharmacol 42:2244-2246

13. Xu DP, Wells WW (1996) alpha-Lipoic acid dependent regeneration of ascorbic acid from dehydroascorbic acid in rat liver mitochondria. J Bioenerg Biomembranes 28:77-85

14. Lykkesfeldt J, Hagen TM, Vinarsky V, Ames BN (1998) Ageassociated decline in ascorbic acid concentration, recycling, and biosynthesis in rat hepatocytes - eversal with $(R)$-alpha-lipoic acid supplementation. FASEB J 12:1183-1189

15. Suh JH, Shigeno ET, Morrow JD, Cox B, Rocha AE, Frei B, Hagen TM (2001) Oxidative stress in the aging rat heart is reversed by dietary supplementation with $(R)$-(alpha)-lipoic acid. FASEB J 15:700-706

16. Michels AJ, Joisher N, Hagen TM (2003) Age-related decline of sodium-dependent ascorbic acid transport in isolated rat hepatocytes. Arch Biochem Biophys 410:112-120

17. Han D, Handelman G, Marcocci L, Sen CK, Roy S, Kobuchi H, Tritschler HJ, Flohe L, Packer L (1997) Lipoic acid increases de novo synthesis of cellular glutathione by improving cystine utilization. Biofactors 6:321-338

18. Ou P, Tritschler HJ, Wolff SP (1995) Thioctic (lipoic) acid: a therapeutic metal chelating antioxidant? Biochem Pharmacol 50:123-126

19. Suh JH, Moreau R, Heath SH, Hagen TM (2005) Dietary supplementation with $(R)$-alpha-lipoic acid reverses the agerelated accumulation of iron and depletion of antioxidants in the rat cerebral cortex. Redox Rep 10:52-60

20. Lodge JK, Traber MG, Packer L (1998) Thiol chelation of $\mathrm{Cu}^{2+}$ by dihydrolipoic acid prevents human low density lipoprotein peroxidation. Free Radic Biol Med 25:287-297

21. Bush AI (2002) Metal complexing agents as therapies for Alzheimer's disease. Neurobiol Aging 23:1031-1038

22. Goralska M, Dackor R, Holley B, McGahan MC (2003) Alphalipoic acid changes iron uptake and storage in lens epithelial cells. Exp Eye Res 76:241-248

23. Patel MS, Packer L (2008) Lipoic acid: energy production, antioxidant activity and health effects (oxidative stress and disease). Taylor \& Francis, Boca Raton

24. Vasdev S, Ford CA, Parai S, Longerich L, Gadag V (2000) Dietary lipoic acid supplementation prevents fructose-induced hypertension in rats. Nutr Metab Cardiovasc Dis 10:339-346

25. Vasdev S, Ford CA, Parai S, Longerich L, Gadag V (2000) Dietary alpha-lipoic acid supplementation lowers blood pressure in spontaneously hypertensive rats. J Hypertens 18:567-573

26. Vasdev S, Gill V, Longerich L, Parai S, Gadag V (2003) Saltinduced hypertension in WKY rats: prevention by alpha-lipoic acid supplementation. Mol Cell Biochem 254:319-326

27. Vasdev S, Gill V, Parai S, Gadag V (2005) Dietary lipoic acid supplementation attenuates hypertension in Dahl salt sensitive rats. Mol Cell Biochem 275:135-141

28. Louhelainen M, Merasto S, Finckenberg P, Lapatto R, Cheng ZJ, Mervaala EM (2006) Lipoic acid supplementation prevents cyclosporine-induced hypertension and nephrotoxicity in spontaneously hypertensive rats. J Hypertens 24:947-956

29. Takaoka M, Kobayashi Y, Yuba M, Ohkita M, Matsumura Y (2001) Effects of alpha-lipoic acid on deoxycorticosterone acetatesalt-induced hypertension in rats. Eur J Pharmacol 424:121-129

30. Midaoui AE, de Champlain J (2002) Prevention of hypertension, insulin resistance, and oxidative stress by alpha-lipoic acid. Hypertension 39:303-307

31. Midaoui AE, Elimadi A, Wu L, Haddad PS, de Champlain J (2003) Lipoic acid prevents hypertension, hyperglycemia, and the increase in heart mitochondrial superoxide production. Am J Hypertens 16:173-179

32. Kramer K, Packer L (2001) R-alpha-lipoic acid. In: Kramer K, Hoppe P, Packer L (eds) Nutraceuticals in health and disease prevention. Marcel Dekker, New York, pp 129-164

33. Marracci GH, Jones RE, McKeon GP, Bourdette DN (2002) Alpha-lipoic acid inhibits T cell migration into the spinal cord and suppresses and treats experimental autoimmune encephalomyelitis. J Neuroimmunol 131:104-114

34. Morini M, Roccatagliata L, Dell'Eva R, Pedemonte E, Furlan R, Minghelli S, Giunti D, Pfeffer U, Marchese M, Noonan D, 
Mancardi G, Albini A, Ucelli A (2004) Alpha-lipoic acid is effective in prevention and treatment of experimental autoimmune encephalomyelitis. J Neuroimmunol 148:146-153

35. Yadav V, Marracci G, Lovera J, Woodward W, Bogardus K, Marquardt W, Shinto L, Morris C, Bourdette D (2005) Lipoic acid in multiple sclerosis: a pilot study. Mult Scler 11:159-165

36. Yadav V, Marracci GH, Munar MY, Cherala G, Stuber LE, Alvarez L, Shinto L, Koop DR, Bourdette DN (2010) Pharmacokinetic study of lipoic acid in multiple sclerosis: comparing mice and human pharmacokinetic parameters. Mult Scler 16:387-397

37. Schupke H, Hempel R, Peter G, Hermann R, Wessel K, Engel J, Kronbach T (2001) New metabolic pathways of alpha-lipoic acid. Drug Metab Dispos 29:855-862

38. Harrison EE, McCormick DB (1974) The metabolizm of dl-(1,6- $\left.{ }^{14} \mathrm{C}\right)$ lipoic acid in the rat. Arch Biochem Biophys 160:514-522

39. Shang YJ, Qian YP, Liu XD, Dai F, Shang XL, Jia WQ, Liu Q, Fang JG, Zhou B (2009) Radical-scavenging activity and mechanism of resveratrol-oriented analogues: influence of the solvent, radical, and substitution. J Org Chem 74:5025-5031

40. Klein E, Rimarčík J, Lukeš V (2009) DFT/B3LYP study of the $\mathrm{O}-\mathrm{H}$ bond dissociation enthalpies and proton affinities of para- and meta-substituted phenols in water and benzene. Acta Chim Slovaca 2:37-51

41. Mikulski D, Górniak R, Molski M (2010) A theoretical study of the structure-radical scavenging activity of trans-resveratrol analogues and $c i s$-resveratrol in gas phase and water environment. Eur J Med Chem 45:1015-1027

42. Wright JS, Johnson ER, DiLabio GA (2001) Predicting the activity of phenolic antioxidants: theoretical method, analysis of substituent effects, and application to major families of antioxidants. J Am Chem Soc 123:1173-1183

43. Leopoldini M, Marino T, Russo N, Toscano M (2004) Antioxidant properties of phenolic compounds: $\mathrm{H}$-atom versus electron transfer mechanism. J Phys Chem A 108:4916-4922

44. Cao H, Pan XL, Li C, Zhou C, Deng FY, Li TH (2003) Density functional theory calculations for resveratrol. Bioorg Med Chem Lett 13:1869-1871

45. Frisch MJ, Trucks GW, Schlegel HB, Scuseria GE, Robb MA, Cheeseman JR, Montgomery JA Jr, Vreven T, Kudin KN, Burant JC, Millam JM, Iyengar SS, Tomasi J, Barone V, Mennucci B, Cossi M, Scalmani G, Rega N, Petersson GA, Nakatsuji H, Hada M, Ehara M, Toyota K, Fukuda R, Hasegawa J, Ishida M, Nakajima T, Honda Y, Kitao O, Nakai H, Klene M, Li X, Knox JE, Hratchian HP, Cross JB, Bakken V, Adamo C, Jaramillo J, Gomperts R, Stratmann RE, Yazyev O, Austin AJ, Cammi R, Pomelli C, Ochterski JW, Ayala PY, Morokuma K, Voth GA, Salvador P, Dannenberg JJ, Zakrzewski VG, Dapprich S, Daniels AD, Strain MC, Farkas O, Malick DK, Rabuck AD, Raghavachari K, Foresman JB, Ortiz JV, Cui Q, Baboul AG, Clifford S, Cioslowski J, Stefanov BB, Liu G, Liashenko A, Piskorz P, Komaromi I, Martin RL, Fox DJ, Keith T, Al-Laham MA, Peng CY, Nanayakkara A, Challacombe M, Gill PMW, Johnson B, Chen W, Wong MW, Gonzalez C, Pople JA (2004) Gaussian 03, revision $\mathrm{C} 02$. Gaussian Inc., Wallingford
46. Hohenberg K, Kohn W (1964) Inhomogeneous electron gas. Phys Rev 136:B864-B871

47. Kohn W, Sham LJ (1965) Self-consistent equations including exchange and correlation effects. Phys Rev A 140:1133-1138

48. Lee C, Yang W, Parr RG (1988) Development of the ColeSalvetti correlation energy formula into a functional of the electron density. Phys Rev B 37:785-789

49. Møller C, Plesset MP (1934) Note on an approximation treatment for many-electron systems. Phys Rev 46:618-622

50. Leopoldini M, Russo N, Toscano M (2011) The molecular basis of working mechanism of natural polyphenolic antioxidants. Food Chem 125:288-306

51. Foti MC, Daquino C, Geraci C (2004) Electron-transfer reaction of cinnamic acids and their methyl esters with the DPPH. radical in alcoholic solutions. J Org Chem 69:2309-2314

52. Litwinienko G, Ingold KU (2004) Abnormal solvent effects on hydrogen atom abstraction. 2. Resolution of the curcumin antioxidant controversy. The role of sequential proton loss electron transfer. J Org Chem 69:5888-5896

53. Musialik M, Litwinienko G (2005) Scavenging of dpph. radicals by vitamin $\mathrm{E}$ is accelerated by its partial ionization: the role of sequential proton loss electron transfer. Org Lett 7:4951-4954

54. Nakanishi I, Kawashima T, Ohkubo K, Kanazawa H, Inami K, Mochizuki M, Fukuhara K, Okuda H, Ozawa T, Itoh S, Fukuzumi $\mathrm{S}$, Ikota N (2005) Electron-transfer mechanism in radicalscavenging reactions by a vitamin $\mathrm{E}$ model in a protic medium. Org Biomol Chem 3:626-629

55. Litwinienko G, Ingold KU (2007) Solvent effects on the rates and mechanisms of reaction of phenols with free radicals. Acc Chem Res 40:222-230

56. Parker VD (1992) Homolytic bond (H-A) dissociation free energies in solution - applications of the standard potential of the $\left(\mathrm{H}^{+} / \mathrm{H}\right)$ couple. J Am Chem Soc 114:7458-7462

57. Bizarro MM, Cabral BJC, dos Santos RMB, Simões JAM (1999) Substituent effects on the $\mathrm{O}-\mathrm{H}$ bond dissociation enthalpies in phenolic compounds: agreements and controversies. Pure Appl Chem 71:1249-1256

58. Atkins PW (1998) Physical chemistry, 6th edn. Oxford University Press, Oxford

59. Cossi M, Rega N, Scalmani G, Barone V (2003) Energies, structures, and electronic properties of molecules in solution with the C-PCM solvation model. J Comput Chem 24:669-681

60. Mikulski D, Molski M (2010) Quantum chemistry study of interaction of $\mathrm{Cu}^{2+}$ cation and aqua-copper $\left[\mathrm{Cu}\left(\mathrm{H}_{2} \mathrm{O}\right)_{1-4}\right]^{2+}$ complexes with resveratrol. J Mol Struct THEOCHEM 956:66-76

61. Mikulski D, Szelagg M, Molski M, Górniak R (2010) Quantumchemical study on the antioxidation mechanisms of trans-resveratrol reactions with free radicals. In the gas phase, water and ethanol environment. J Mol Struct THEOCHEM 951:37-48

62. Mikulski D, Szelagg M, Molski M (2011) Quantum-chemical study of interactions of trans-resveratrol with guanine-thymine dinucleotide and DNA-nucleobases. J Mol Model. doi:10.1007/s00894011-0999-2 